\title{
Ekonomi Politik Eksploitasi Khalayak sebagai Buruh dalam Serial Sinetron Tukang Bubur Naik Haji
}

\author{
YASIR \\ Jurusan Ilmu Komunikasi FISIP Universitas Riau, JI. HR Soebrantas KM 12,5 Pekanbaru \\ email: yasirjufri@gmail.com
}

\begin{abstract}
Television is a very important tool to accumulate the capital. Among many kinds of television programs, soap opera is the most popular and watched by the people. The purpose of this study was to reveal the exploitation of audience who consumes the Tukang Bubur Naik Haji (TBNH) soap opera at RCTI. This research uses a political economy of communication. To collect the data, the researcher used in-depth interview, observation, documentation, and literature study. The result shows that the main audience of this soap opera is dominantly women Moslem. The audience's activity in consumming was commodified to be exploited by the capital owner. This activity of consuming is also as a main means of production through the rating system to produce the soap opera continuously. So that the audience work as labor to accumulate the capital.
\end{abstract}

Key words: political economy of communication, exploitation, audience, dan soap opera.

\begin{abstract}
Abstrak. Televisi merupakan alat yang sangat penting untuk mengakumulasikan modal. Di antara banyak jenis program televisi, sinetron adalah salah satu program yang paling populer dan banyak ditonton oleh masyarakat Indonesia. Oleh karena itu, tulisan ini berusaha untuk mengungkap bentuk eksploitasi terhadap khalayak dalam mengkonsumsi sinetron Tukang Bubur Naik Haji (TBNH) di RCTI.Penelitian ini menggunakan paradigma kritis dengan kajian ekonomi politik komunikasi. Pengumpulan data dilakukan dengan wawancara mendalam, penelusuran dokumen dan kepustakaan. Hasil penelitian ini menunjukkan bahwa eksploitasi khalayak sinetron TBNH ini terjadi pada umat Islam khususnya kaum perempuan sebagai target konsumen utama televisi tersebut. Aktivitas khalayak ini dijadikan komoditas untuk terus dieksploitasi. Aktivitas konsumsi ini menjadi alat produksi utama bagi pemilik media dalam keberlangsungan sinetron untuk terus ditayangkan. Khalayak menjadi komponen utama yang dipekerjakan dalam mengkonsumsi sinetron, sebagai buruh yang memproduksi rating. Oleh karena itu, kegiatan ini adalah bentuk khalayak sebagai buruh yang berkerja untuk mengakumulasi kepentingan pemodal.
\end{abstract}

Kata Kunci: ekonomi politik komunikasi, eksploitasi, khalayak, dan sinetron.

\section{Pendahuluan}

Televisi merupakan alat yang sangat penting untuk mengakumulasikan modal. Nixon (2014: 725) mengatakan bahwa komunikasi adalah modal. Nixon mengungkapkan bahwa modal yang bersirkulasi dan mengakumulasi melalui proses komunikasi disebut sebagai modal yang komunikatif. Ada banyak fenomena yang menunjukkan bahwa konglomerat saat ini berusaha untuk mengintegrasikan usahanya dengan bidang komunikasi. Di sisi lain, Sulaiman (2010: 117) juga menegaskan bahwa televisi memiliki kekuatan daya jangkauan luas, sehingga mampu menggantikan fungsi organisasi partai politik untuk menjangkau calon pemilih. Televisi memang masih menjadi media utama baik sebagai media hiburan atau media informasi sebagai pilihan masyarakat Indonesia. Data Badan Pusat Statistik (BPS) tahun 2009 menunjukkan ada 90,27\% dan tahun 2012 ada $91,68 \%$ penduduk Indonesia umur 10 tahun ke atas menonton televisi (www.bps. go.id, diakses 3 Maret 2014).

Data Nielsen menyebutkan bahwa belanja iklan di media televisi saja tahun 2013 sebesar Rp 73 triliun, dengan porsi sebesar

Received: 29 Januari 2015, Revision: 25 April 2015, Accepted: 25 Mei 2015

Print ISSN: 0215-8175; Online ISSN: 2303-2499. Copyright@2015. Published by Pusat Penerbitan Universitas (P2U) LPPM Unisba Terakreditasi SK Kemendikbud, No.040/P/2014, berlaku 18-02-2014 s.d 18-02-2019 
$68 \%$. Jumlah ini mendominasi total belanja iklan media secara keseluruhan yaitu Rp 106 triliun (Newsletter Nielsen Januari 2014). Ini menunjukkan bahwa industri televisi menyedot perhatian khalayak masyarakat dengan berbagai program tayangan yang dimilikinya.

Salah satu program acara televisi yang populer adalah sinema elektronik (sinetron). Sinetron merupakan program acara televisi unggulan bagi beberapa stasiun televisi tertentu, bahkan sering mendapatkan rating tertinggi. Sejalan dengan ini, Cetin (2014: 2463) menjelaskan bahwa banyak sinetron atau drama televisi dibeberapa negara telah dieksploitasi oleh negara untuk kepentingan politik dalam membangun identitas bangsa, seperti di negara lainnya, di India (Mankekar, 1999; Rajagopal, 2001), Mesir (Abu-Loghud, 2005), China (Rofel, 2002), Brasil (Porto, 2011; Tufte, 2000) dan seterusnya. Kitley (1998) juga menjelaskan fenomena ini di masa Orde Baru, dengan fokus sinetron Keluarga Rahmat. Ketika televisi swasta seperti RCTI, SCTV, ANTV muncul di awal 1990-an, tema sinetron bergeser sejalan dengan persaingan merebut khalayak atau pasar.

Pasca era reformasi (1998), banyak muncul televisi swasta baru yang meramaikan persaingan. Salah satu tayangan yang menyasar masyarakat Islam adalah dengan sinetron genrereligi. Sinetron ini mulai melejit meramaikan televisi nasional berbarengan dengan sinetron lainnya di awal tahun 2000an. Simbol agama banyak dikomodifikasi oleh sinetron kategori ini untuk mengikuti tren pemintaan pasar. Awalnya sinetron religi ini lebih banyak berbau mistik. Belakangan sinetron religi mistik ini bergeser dan berubah bentuknya ke sinetron religi yang bercerita pada kehidupan sehari-hari. Beberapa di antaranya yang popular adalah Tukang Bubur Naik Haji, Ustadz Fotocopy, Islam KTP, AnakAnak Manusia, Emak Ijah Pengen Ke Mekah, Para Pencari Tuhan (PPT) dan lain sebagainya. Perubahaan atau pergeseran ini sebenarnya hanya kedok industri televisi untuk menarik pemirsa.

Penelitian Syahputra (2011: 334) menunjukkan bahwa simbolisasi religius dalam sinetron pada dasarnya melayani dua sektor secara bersamaan. Pertama, melayani kepuasan religius simbolik khalayak. Dengan menggunakan simbol agama, seakanakan religiusitas penonton diajak bahkan dipaksa untuk terlibat. Pemaksaan tersebut berlangsung dengan halus melalui rayuan- rayuan simbolik tadi. Kedua, simbolisasi religius melayani pasar pengiklan. Pasar pengiklan sebenarnya secara langsung tidak berkepentingan terhadap digunakan atau tidak simbol agama oleh televisi. Namun melalui simbol agama Islam yang digunakan, televisi meraih banyak jumlah penonton.

Gokariksel \& McLearny (2010:1) juga mengungkapkan bahwa "Islam" telah membantu penciptaan industri budaya baru dan pangsa pasar baru untuk komoditas, media, iklan, bisnis dan segmentasi konsumen. Sinetron religi ini dikemas dengan unsur-unsur lain, seperti drama, cinta dan komedi tentu akan menjadi sebuah bisnis yang cukup menjanjikan. Sinetron tersebut muncul karena adanya tren yang sedang berkembang, komoditas yang menarik untuk pangsa pasar masyarakat Indonesia yang mayoritas beragama Islam, menyukai hal-hal yang lucu dan berbau hiburan.

Tulisan ini fokus untuk mengungkap ekonomi politik eksploitasi khalayak sebagai buruh dalam sinetron Tukang Bubur Naik Haji (TBNH) yang tayang di RCTI.TBNH merupakan sinetron yang diproduksi oleh rumah produksi SinemaArt. Pertama kali tayang pada Senin tanggal 28 Mei 2012 dan hingga kini masih terus tayang dengan lebih dari 1500 episode. Selain mendapatkan penghargaan sebagai sinetron yang terpanjang dari Museum Rekor Indonesia (MURI), dua kali dari Panasonic Gobel Award (PGA) dan juga dari International Drama Festival in Tokyo tahun 2014 untuk kategori drama asing terbaik. Penghargaan International Drama Festival di Tokyo ini lebih menyoroti sinetron dari sisi "kemampuan pemasaran" dan "kemampuan menjual" dibandingkan "kualitas acara" atau "segi artistik" dari drama yang masuk nominasi (www.merdeka.com, diakses 24 Oktober 2014).

Keberhasilan sinetron ini tidak terlepas dari aktivitas konsumsi khalayak yang terjebak untuk terus menonton tayangan sinetron ini. Jadi hal yang tidak bisa dihindari adalah aktivitas khalayak yang dijadikan sebagai komoditas dan juga sebagai buruh untuk bekerja demi keuntungan para pengiklan dan pemilik media itu sendiri. Oleh karena itu, komodifikasi tenaga kerja khalayak secara berlebihan ini memunculkan proses eksploitasi karena eksploitasi adalah bagian yang tidak terpisahkan dari proses kerja kapitalis.

\section{Teori Ekonomi Politik Komunikasi}


McQuail (2010: 105) menjelaskan bahwa teori ekonomi politik adalah pendekatan kritik sosial yang berfokus pada hubungan antara struktur ekonomi dan dinamika industri media serta konten ideologis media. Dari sudut pandang ini, media dianggap sebagai bagian dari sistem ekonomi dengan hubungannya dengan sistem politik. McQuail menjelaskan beberapa proposisi utama dari teori ekonomi politik media, sebagaimana berikut:

\begin{abstract}
"Kontrol ekonomi dan logika selalu menentukan; Struktur media selalu cenderung menuju monopoli; Integrasi global kepemilikan media berkembang; Konten dan khalayak dijadikan komoditas (komodifikasi); Keragaman yang sesungguhnya menurun; Oposisi dan suara alternatif dipinggirkan; Kepentingan publik dalam komunikasi dikesampingkan demi kepentingan pribadi; Akses terhadap keuntungan komunikasi disebarkan secara tidak merata" (McQuail, 2010:106).
\end{abstract}

Sejalan dengan proposisi itu, para teoritikus ekonomi politik mempelajari kendali elit atas institusi ekonomi yang kemudian mempengaruhi banyak institusi sosial lain termasuk media massa. Herb Schiller (dalam Baran dan Davis, 2010: 263), menjelaskan bahwa pengaruh korporasi ada di hampir setiap aspek masyarakat. Pengaruhnya dari yang sangat sederhana seperti menu sehari-hari dan pakaian yang kita kenakan, hingga hal-hal bersekala besar seperti cara kita berkomunikasi satu sama lain. Dalam hal ini, Mosco (2009:1118) mengajukan tiga konsep yang sangat mendasar terkait dengan teori ekonomi politik media dalam industri komunikasi, yaitu: komodifikasi (commodification); spasialisasi (spatialization); dan strukturasi (structuration).

Konsep komodifikasi mengacu pada pemanfaatan barang dan jasa yang dilihat dari kegunaanya yang kemudian ditransformasikan menjadi komoditas yang dinilai dari maknanya di pasar. Intinya komodifikasi merupakan proses transformasi nilai guna menjadi nilai tukar (Mosco, 2009: 127). Mosco (2009:133156) juga menguraikan beberapa bentuk komodifikasi dalam komunikasi. Pertama, komodifikasi isi (the commodification of conten) yang merupakan proses perubahan pesan dari kumpulan informasi ke dalam sistem makna dalam wujud produk yang dipasarkan. Kedua, komodifikasi khalayak (the commodification of audience), yang merupakan proses modifikasi peran khalayak oleh perusahaan media dan pengiklan, dari fungsi awal sebagai konsumen media menjadi konsumen khalayak selain media. Ketiga, komodifikasi pekerja (labour commodification) yang merupakan penggerak kegiatan produksi dan juga distribusi.

Sebagai fokus bahasan utama, tulisan ini hanya membahasa komodifikasi khalayak saja. Konsep ekonomi politik komodifikasi khalayak banyak dibahas oleh beberapa ahli. Konseptualisasi Smythe (1977) terkait khalayak banyak dijadikan rujukan untuk menjelaskan bagaimana khalayak menjadi komoditas dan sebagai buruh (Mosco, 2009: 137). Selain itu, Symythe (1977: 6) juga menjelaskan bahwa kegiatan "buruh khalayak" adalah sama dengan pelayan bagi para pengiklan, atau dengan kata lain menjadi agen pemasaran.

Terkait dengan ini, Terranova (2000) adalah sebagai sarjana pertama yang secara detil membahas ekonomi politik buruh media digital, yang digambarkan sebagai buruh gratis (free labour) (Nixon, 2014: 716). Beberapa peneliti yang terkait dengan aktivitas khalayak pengguna komunikasi digital ini sebagai buruh adalah Andrejevic (2011), Choen (2008), Funch (2011), Kang \& McAllister (2011) Manzerolle (2010) dan McStay (2011) serta Fisher (2012). Mereka melanjutkan teori ekonomi politik yang mengungkapkan penjualan data khalayak kepada pengiklan dari data yang dikumpul melalui pengukuran yang ada. Ada beberapa kemajuan dari ide Smythe yang berkembang dari penelitian mereka yaitu, penjualan para pengguna, prosumer atau buruh digital (perhatian mereka) ke pengiklan.

Beberapa hal yang berkembang adalah adanya eksploitasi buruh dalam budaya digital. Penelitian dalam media digital belum menunjukkan hubungan yang jelas antara eksploitasi dan akumulasi modal. Tidak banyak peneliti yang mengungkap keterkaitan antara modal komunikatif dan buruh khalayak sebagai penonton dan komoditas untuk dieksploitasi. Oleh karena itu, penulis berusaha membongkar relasi hubungan televisi sebagai modal dan alat pengkontrol produksi komunikatif terhadap proses konsumsi sinetron sebagai bentuk eksploitasi terhadap buruh khalayak.

\section{Metode Penelitian}

Kajian ini menggunakan pendekatan kritis dengan teori ekonomi politik komunikasi. Konsep komodifikasi khalayak yang dikembangkan oleh Vincent Mosco 
(2009: 11) dan eksploitasi buruh khalayak (audience labour) oleh Dallas Smythe (1977) dan Brice Nixon (2014: 726) menarik menjadi pisau bedah masalah penelitian ini. Tulisan ini lebih fokus mengkaji pada bentuk eksploitasi khalayak baik sebagai bentuk menjadikan mereka sebagai komoditas dan buruh secara bersamaan untuk terus mengkonsumsi sinetron religi $\mathrm{TBNH}$ yang ditayangkan oleh RCTI.

Teknik pengumpulan data pada penelitian ini adalah dokumentasi, wawancara mendalam, studi kepustakaan/literatur, penelusuran internet dan juga melakukan observasi. Dokumentasi yang digunakan adalah laporan tahunan MNC dan juga data dari lembaga pemeringkat yaitu dari Nielsen. Sedangkan wawancara mendalam dilakukan kepada informan yang dipilih secara purposif kepada orang-orang tertentu yang memiliki informasi dengan data penelitian. Observasi juga peneliti lakukan untuk memahami konteks proses produksi dan distribusi serta bagaimana sinetron TBNH ini dikonsumsi. Studi literatur ditujukan untuk mendalami, menelaah, dan mengidentifikasi pengetahuan yang ada dalam kepustakaan. Penelusuran internet juga peneliti gunakan untuk tujuan pembanding, audit dan pengecekan data yang diambil.

\section{Pola Konsumsi Sinetron TBNH}

Pola konsumsi sinetron TBNH melibatkan banyak hal, dari kesukaan khalayak pada bintang sinetron yang memerankan karakter tertentu, keinginan mengisi waktu luang dan sampai ada yang ketergantungan/kecanduan dengan sinetron ini. Namun yang tidak banyak disadari oleh khalayak adalah bahwa kegiatan mengkonsumsi ini adalah bentuk eksploitasi yang dilakukan oleh pemodal dan pemilik televisi untuk mengakumulasi modalnya. Sebagaimana dijelaskan oleh Smythe (dalam Mosco, 2009: 136) bahwa

aktivitas konsumsi khalayak adalah kegiatan media massa untuk menjadikan khalayak sebagai komoditas utama dan buruh sekaligus.

Ada hubungan yang sangat signifikan antara pola aktivitas konsumsi khalayak dan akumulasi modal. Ini terlihat dari bagaimana media massa memproduksi dan menjual khalayak sebagai komoditas kepada pengiklan. Konsep "buruh khalayak" dalam ekonomi politik komunikasi dipisahkan dan dikonsep ulang oleh Nixon (2014: 714). Khalayak sebagai buruh dalam konteks ini adalah aktivitas konsumsi khalayak yang dilihat sebagai aktivitas produksi, yang memudahkan para pekerja media baik stasiun RCTI dan Sinemart sebagai rumah produksi $(\mathrm{PH})$ untuk terus melakukan perubahan dalam menyajikan tayangan sinetron TBNH. Oleh karena itu, pola konsumsi masyarakat terhadap sinetron ini juga berhubungan dengan pola dan rutinitas media (media routine) baik memproduksi dan menayangkan sinetron, termasuk promosi yang gencar dilakukan. Promosi dan pemasaran program televisinya didasarkan pada strategi utama yang dimiliki oleh pihak RCTI yang banyak memfokuskan pada program sinetron. Karena program sinetron selalu mendapatkan rating yang bagus.

Sistem rating ini merupakan sebuah kekuatan yang hegemonik dalam mengatur dan menentukan strategi televisi dan bercerita dalam sinetron atau tayangan televisi umumnya. Berbagai strategi dilakukan seperti mendatangkan pemain bintang baru atau alur cerita yang dibagi kedalam banyak plot. Strategi ini berguna untuk menarik khalayak agar terus loyal menonton. Jadi eksploitasi buruh khalayak terjadi ketika pemilik media dan pemodal berusaha memanfaatkan khalayak menjadi bagian aktivitas produksi dan sekaligus konsumsi sinetron TBNH ini. Karena dalam proses komunikasi, konsumsi khalayak adalah memproduksi makna yang ada dalam sinetron (means of meaning production). Dengan kata lain, khalayak tidak saja menciptakan makna, namun menciptakan uang (not only meaning making, but also money making).

Segmentasi utama khalayak RCTI adalah pada kelompok perempuan, karena memang perempuan yang banyak menggandrungi sinetron. Sinetron TBNH tentu ditujukan untuk segmentasi kelompok masyarakat Islam. Penayangan TBNH dilakukan pada waktu prime time sebagai waktu yang paling banyak atau puncak waktu ditonton oleh khalayak. RCTI dengan berbagai strategi pemasaran dan jaringan media di bawah kelompok MNC "memaksa" khalayak untuk menonton tayangan yang ada. Terkait dengan ini, Komisaris Utama MNC, Rosano Barack mengungkapkan bahwa;

"RCTI dan MNCTV berhasil mempertahankan tingkat rating yang dominan di serial drama dimana enam dari sepuluh program drama terpopuler ditayangkan oleh kedua stasiun TV tersebut. Program drama seri prime time kami yaitu "Tukang Bubur Naik Haji" berhasil menjadi program drama 
seri terpopuler di tahun 2013 dan telah ditayangkan lebih dari 1.000 episode. Ke depannya, kami akan terus fokus untuk memproduksi dan menayangkan program drama seri berkualitas yang menghibur penonton setia kami (Laporan Tahunan MNC 2013).

Keberhasilan sinetron TBNH yang mampu menarik pengiklan tentu menjadi kebanggaan buat pemilik televisi. Karena dari berbagai tayangan acara hiburan, sinetron atau drama jelas menjadi unggulan bagi grup MNC dan khususnya RCTI dan MNCTV. RCTI adalah salah satu televisi yang paling banyak menayangkan sinetron. RCTI dari 2012 hingga 2015 sudah mengandalkan sinetron TBNH, sampai harus menghilangkan beberapa sinetron yang lain karena popularitasnya. Sejalan dengan ini, Direktur Utama MNC Hary Tanosoedibjo mengungkapkan bahwa:

"Produksi konten yang strategis selalu
menjadi kunci kesuksesan kami. Tidak
cukup dengan hanya memproduksi
program-program berkualitas. Kami
telah bekerja untuk memproduksi
konten yang tepat sehingga menarik
perhatian penonton wanita sebagai
salah satu segmen demografi paling
menguntungkan. Konten inilah yang pada
akhirnya menjadikan MNC sebagai pilihan
terbaik bagi pengiklan dan mendorong
pertumbuhan pendapatan. Program-
program kami mengungguli para pesaing
kami, terutama pada program drama dan
pencarian bakat......" (Laporan Tahunan
MNC 2013).

Wanita jelas menjadi sasaran utama RCTI, karena keberhasilan RCTI meraih pangsa pasar tidak terlepas dari pilihan segmen khalayak perempuan. Sinetron TBNH sebagai salah satu sinetron unggulan dalam meraih pemirsa dimanfaatkan oleh pemilik televisi untuk terus diproduksi dan dipertahankan dengan sebanyak mungkin episodenya. Dalam perebutan pemirsa yang dilakukan oleh antarstasiun televisi, banyak strategi berubah menyesuaikan keinginan pasar. Banyak judul sinetron terus bermunculan dan menggantikan yang telah dihilangkan.

Tabel 1: Lima Sinetron Terpopuler Tahun 2013

\begin{tabular}{|c|l|c|c|c|}
\hline No & Programe Name & Channel & TVR & Share \\
\hline 1 & $\begin{array}{l}\text { Tukang Bubur } \\
\text { Naik Haji }\end{array}$ & RCTI & 5.8 & 22.8 \\
\hline 2 & $\begin{array}{l}\text { Kami Rindu } \\
\text { Ayah }\end{array}$ & SCTV & 4.2 & 17.2 \\
\hline
\end{tabular}

\begin{tabular}{|c|l|c|c|c|}
\hline 3 & $\begin{array}{l}\text { Anak-Anak } \\
\text { Manusia }\end{array}$ & RCTI & 4.1 & 18.4 \\
\hline 4 & Berkah & RCTI & 4.1 & 17.5 \\
\hline 5 & $\begin{array}{l}\text { Diam-Diam } \\
\text { Suka }\end{array}$ & IVM & 3.9 & 15.9 \\
\hline
\end{tabular}

Sumber: Nielsen

TBNH menjadi sinetron yang mampu bertahan dan konsisten di peringkat teratas sepanjang 2013, bahkan tetap terus bertahan hingga tahun 2015 meski tidak selalu di peringkat di atas. Ini membuktikan sinetron ini memiliki "buruh" yang loyal untuk tetap mendatangkan pengiklan dan keuntungan bagi pemodal. Perolehan rating TBNH sepanjang tahun 2013 dapat dilihat pada tabel 1.

Tabel 1 tersebut menunjukkan keberhasilan sinetron $\mathrm{TBNH}$, hal ini tidak terlepas dari strategi bercerita dengan menggunakan tema/simbol Islam dan budaya Betawi untuk menyasar khalayak Muslim. Keberhasilan RCTI dan MNC secara keseluruhan dalam mengemas sinetron dan berbagai tayangan lainnya sangat memberikan pengaruh pada dominasi grup media ini dalam perolehan pangsa pasar sepanjang tahun 2013. Seperti yang terlihat pada gambar berikut.

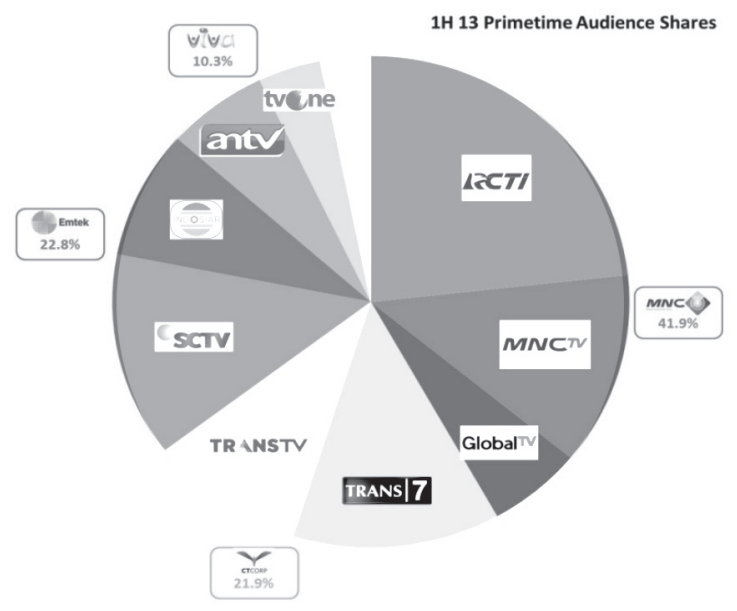

Sumber:www.startupbisnis.com, diakses 11 Januari 2015.

\section{Gambar 1. Pangsa Pasar Televisi Prime Time Rata-rata Tahun 2013}

Gambar 1 tersebut menunjukkan bahwa persaingan televisi selalu diperebutkan antara kelompok MNC (RCTI), EMTEK (SCTV), CT Corp, dan Viva. Persaingan sebenarnya tidak terjadi antar stasiun televisi, namun yang ada adalah persaingan antar jaringan 
kelompok pemilik televisi. Dominasi kelompok yang menjadikan sinetron sebagai tayangan unggulan terjadi antara group MNC (RCTI) dan EMTEK (SCTV), serta ANTV yang mulai tahun 2014 menayangkan sinetron (drama serial) impor dari India seperti Mahabarata, Ramayana, Jhoda Akbar, dll dan juga dari Turki seperti King of Sulaiman (Abad Kejayaan).

Tren sinetron selalu berubah, namun TBNH tetap mampu bertahan. Agar sinetron TBNH bisa terus menerus diproduksi dan dikonsumsi, maka berbagai upaya pun dilakukan agar tema selalu mengikuti tren yang berkembang di masyarakat. Berbagai strategi yang bersifat kontemporer, mengikuti tren dan budaya yang ada di masyarakat inilah kunci sukses TBNH. Di sisi lain, selera masyarakat jelas dibentuk, diubahubah dan dibolak-balik oleh produsen yang menggunakan sistem kode dalam produksi sinetron TBNH yang hadir setiap hari di RCTI dengan modus stripping ini.

\section{Konsumsi Sinetron Cepat saji}

Sebagaimana dijelaskan sebelumnya pola konsumsi masyarakat Indonensia cenderung menyukai acara hiburan khususnya sinetron. Tingginya tingkat konsumsi sinetron terlihat dari perolehan rating sinetron yang umumnya berada pada peringkat teratas di banding program lainnya. Stasiun televisi pun menggunakan strategi stripping dalam penayangannya agar khalayak terjebak untuk terus mengkonsumsi sinetron. Aktivitas khalayak yang loyal dalam mengkonsumsi sinetron yang diproduksi cepat saji (asal jadi) ini dijadikan pemilik stasiun televisi sebagai komoditas yang dijual ke pengiklan dan sekaligus buruh pekerja untuk mengakumulasi modal.

Aktivitas konsumsi cepat saji oleh khalayak ini jelas merupakan aktivitas produksi, dimana kegiatan khalayak ini diukur melalui rating yang menentukan produksi berikutnya. Dengan kata lain khalayak dipekerjakan untuk memproduksi rating. Aktivitas khalayak sebagai buruh ini beriringan dengan pekerja lain (penulis naskah, sutradara, artis, kru, dlI). Semua pekerja ini menjadi aspek produksi utama kepentingan pemilik media. Salah seorang manajer RCTI mengungkapkan:

"Kita tidak mendesain TBNH untuk sampai ke episode berapa, karena industri kita itu industri yang sangat dinamis yang menentukan adalah pemirsa. Sepanjang pemirsa masih mau menonton TBNH selama itu pula TBNH akan tayang. Ini tentu akan terus diproduksi dengan beragam kreatifitas cerita perkembangannya seperti apa, itu yang harus dipikirkan..... Kalau pemirsanya masih tetep tertarik, tentu akan dipertahankan. Selera pemirsa kan diukur dari rating dan share itu tadi" (FK, Wawancara, 15 Oktober 2014).

Pernyataan di atas jelas menunjukkan bahwa para pekerja media, pekerja sinetron dan terutama khalayak menjadi aspek penting dalam produksi sinetron stripping. Pekerja seperti penulis cerita, sutradara, artis dan programing serta pemasaran RCTI, harus bekerja cepat dan kreatif untuk mencapai rating yang bagus demi memenuhi keinginan pemilik modal. Dalam hal ini, Smythe menegaskan bahwa media massa dan khalayak berperan penting dalam kemajuan kepitalisme. Media massa memproduksi khalayak sebagai komoditas untuk dijual kepada pengiklan (dalam Fisher, 2012:172). Melalui program televisi seperti sinetron, khalayak terjebak untuk menonton sinetron dan sekaligus menonton iklan sebagai motor pengerak konsumsi. Oleh karena itu, Smythe mengubah ide aliran Birmingham terkait khalayak aktif, dari khalayak yang menciptakan makna menjadi khalayak yang menciptakan uang (from the realm of meaning making to that of money making) (dalam Fisher, 2012:172).

Keaktifan khalayak dapat dimaknai bahwa khalayak harus bekerja menghasilkan makna, dari makna-makna yang mereka konsumsi. Produksi aktivitas khalayak adalah makna, jadi buruh khalayak adalah proses penandaan melalui konsumsi budaya (Nixon, 2014: 722). Simbol budaya yang paling dekat dengan kehidupan khalayak adalah agama. Tidak aneh bila RCTI sampai saat ini masih fokus dan memunculkan sinetron bergenre religi terutama bulan ramadhan. Sinemart sebagai PH tentu tidak asal produksi jika tidak ada permintaan dari pihak stasiun televisi RCTI. Namun RCTI sendiri tidak mendesain ini dengan tiba-tiba, ini terkait dengan tren dan hasil riset pasar yang mereka lakukan. Terkait dengan ini, Manajer Programing RCTI mengemukakan:

\footnotetext{
"Mengapa banyak ke religi, itu sebenarnya tidak kita desain secara khusus tayangan religi. Cuma memang ketika kita tayangkan program sinetron religi itu ternyata disukai oleh pemirsa. Kami tidak mendesain sesuai apa yang kami inginkan. Tapi kami mendesain apa yang sesuai pemirsa inginkan. Saat ini ketika pemirsa suka tema-tema berbau religi ya
} 
Tabel 2

Total Belanja Iklan di TBNH RCTI (1 Januari - 31 Desember 2013)

\begin{tabular}{|c|l|l|c|c|}
\hline Channel & \multicolumn{1}{|c|}{ Programme } & $\begin{array}{c}\text { Programme } \\
\text { Typology }\end{array}$ & $\begin{array}{c}\text { No. Of } \\
\text { Spots }\end{array}$ & Cost (in thousand) \\
\hline RCTI & $\begin{array}{l}\text { TUKANG BUBUR NAIK } \\
\text { HAJI THE SERIES }\end{array}$ & Series: Drama & 52.782 & $2.242 .185 .500,00 \mathrm{Rp}$ \\
\hline
\end{tabular}

Sumber: Nielsen

kita jadi bermain di situ. Atau next time selera pemirsa beralih jadi, lets say, ke action ya jadi kami harus mengikuti apa yang pemirsa sukai" (FK, Wawancara, 15 Oktober 2014).

Pola penayangan cepat saji (stripping) ini menunjukkan bahwa sistem produksi sinetron mengikuti logika kapitalis untuk memutar uang dan mengakumulasi modal sebanyak-banyaknya. Dengan strategi stripping, khalayak penonton menjadi terjebak untuk terus mengkonsumsi dan memproduksi rating, dengan kata lain harus menghasilkan uang buat pemilik media. Posisi sinetron TBNH yang selalu masuk 5 besar rating tertinggi dari tahun 2012 hingga 2015, menjadikan sinetron ini sebagai salah satu program acara terlaris saat jam prime time sehingga banyak pemasang iklan yang mengisi slot jeda iklan yang disediakan. Banyaknya pemasang iklan yang berebut slot pada jeda iklan sinetron tersebut, tentu saja ini ikut menambah keuntungan yang didapat dari segi penjualan sinetron TBNH. Di tahun 2013, sinetron ini meraup pengiklan dengan jumlah 52.782 spot dengan jumlah rupiah Rp 2.242.185500.000. Jumlah ini tentu tidak sedikit, karena memang pada periode tertentu TBNH dalam satu kali tayang terdiri dari 2-3 episode, dengan durasi tayang lebih dari empat jam.

Pada tabel 2 menunjukkan bahwa spot iklan yang diperoleh TBNH sepanjang tahun 2013 adalah berjumlah 52.782. Ini berarti bahwa rate card rata-rata per satu spot TBNH adalah sekitar Rp 42.480.000,- per 30 detik. Dengan kata lain, data ini menunjukkan bahwa dari sinetron TBNH ini saja RCTI dapat mendulang keuntungan yang sangat besar sehingga terus berupaya untuk tetap tayang hingga tahun 2015. Bila sepanjang tahun 2013 selalu berada di rating atas, namun tidak selama tahun 2014 posisi TBNH ratingnya naik turun sehingga otomatis perolehan dan pendapatan dari snetron ini pun ikut berpengaruh. Untuk menjelaskan strategi perubahan produksi, distribusi dan konsumsi sinetron ini akan menarik jika dijelaskan dalam perspektif McDonaldisasi. Dalam hal ini, Ritzer (2012: 993-995) menjelaskan perspektif McDonaldisasi sebagai proses yang mengambil prinsip restoran cepat saji. Prinsip tersebut memiliki kesamaan dan selalu ada dalam sinetron religi yang diibaratkan sebagai restoran cepat saji.

Pertama, dari sisi efisiensi, sinetron TBNH menerapkan pola penggarapan sinetron yang serba cepat-mulai dari penulisan skenario, syuting dilokasi pinggiran Jakarta, editing, mixing, sampai finishing semua dikerjakan serba instan dengan tuntutan cerita yang runtut. Efisiensi juga dilakukan dengan memberikan kontrak kepada pekerja. Dalam kontrak tersebut, pemain sinetron dapat bermain dan terikat dalam rumah produksi yang sama.

Kedua, dari sisi kemudahan diperhitungkan yang menempatkan kuantitas di atas kualitas. Tayangan sinetron religi TBNH kemunculannya sebagai mengikuti tren banyaknya jumlah sinetron religi yang beredar pada stasiun-stasiun televisi yang lain. Penonton terjebak pada strategi yang dibuat oleh pengelola stasiun, sehingga menjadi terjebak untuk bertahan di depan televisi. Strategi cerita dibuat dengan banyak plot dan mendatangkan bintang baru, didukung strategi dengan tayang tanpa jeda iklan di awal, karena iklannya banyak muncul bila mendekati klimaks.

Ketiga, dari sisi kemudahan diprediksi yang menunjukkan adanya keseragaman tayangan antara stasiun televisi yang satu dengan yang lain. Tidak adanya perbedaan antara tayangan sinetron yang satu dengan tayangan sinetron yang lain, karena kepemilikan dan kontrol rumah produksi oleh pemilik yang sama. Bahkan meskipun pemilik dan televisinya berbeda, selalu saja bisa diprediksi adanya saling tiru dan saling intip antarstasiun televisi tersebut. Keseragaman tayangan sinetron genre religi dalam memproduksi tayangan yang sama hanya untuk memenuhi konsumen yang sama. 
Keempat, dari sisi kontrol melalui teknologi nonmanusia dapat juga menunjukkan dengan bekerjanya kamera-kamera, lighting, efek visual, tata suara dan lainnya. Televisi sendiri adalah teknologi utama sebagai mesin yang merupakan alat kontrol bagi pekerja dan khalayaknya. Manusia hanya berfungsi sebagai pengoperasi saja dari alat-alat dengan basis teknologi tersebut. Otoritas manusia terbatasi pada keterampilan dan kemampuan mereka dalam mengoperasikan dan melayani teknologi-teknologi tersebut. Secara tidak langsung ini menunjukkan bahwa kontrol manusia yang memiliki nilai dan norma sangat lemah terhadap teknologi yang ada (Ritzer, 2004: 197).

Kelima, dari sisi ketidakrasionalan rasionalitas. Sinetron TBNH banyak menawarkan rasionalitas kebaikan, namun kebaikan yang disajikan merupakan ketidakrasionalan itu sendiri. Sebagai contoh, efesiensi produksi sinetron yang stripping menampilkan tayangan yang sifatnya menipu realitas. Penggambaran masjid, mobil di jalan adalah bentuk permainan teknologi dan visualisasi yang ditampilkan oleh pengeditan gambar yang ada. Tayangan sinetron yang manipulatif dan eksploitatif ini, jelas sangat tidak manusiawi. Banyak proses dehumanisasi terjadi di mana khalayak dan pekerja dipaksa bekerja terus oleh sistem agar keuntungannya dinikmati oleh pemilik modal. Sinetron stripping adalah bentuk sumber degrdasi baik bagi pekerja maupun khalayak pemirsanya itu sendiri.

Perspektif McDonalisasi menunjukkan bahwa khalayak tidak disuguhi tayangan berunsur dakwah atau pendidikan, yang tertanam dalam simbol atau tema-tema yang diangkat dalam sinetron TBNH. Padahal itu semua hanyalah manipulasi untuk menarik pasar yang umumnya masyarakat Islam itu sendiri. Apabila pasar menyukai sinetron tersebut maka eksistensi sinetron akan terus dilanjutkan untuk diproduksi.

Nixon (2014: 718) mengungkapkan bahwa dalam hukum pergerakan modal komunikatif yang terjadi adalah modal diakumulasi melalui komunikasi. Hal ini menjelaskan tentang aspek yang terintegrasi dari produksi, distribusi dan konsumsi dalam teori ekonomi politik. Sebagaimana digambarkan oleh konsep dialektika Marx tentang hubungan produksi-konsumsi dan produksi-distribusi. Oleh karena itu, khalayak sebagai buruh dikonsepkan menjadi alat komunikasi dan sebagai alat produksi.
Dengan menjadikan khalayak sebagai buruh, maka khalayak adalah bagian dari aparat yang terlibat dalam produksi ideologi.

Di sisi lain, Nixon (2014: 721-724) juga mengembangkan teori yang terkait dengan proses khalayak buruh. Pertama, aktivitas khalayak sebagai pencipta makna. Audiens harus bekerja untuk menghasilkan makna dari makna yang mereka konsumsi, sebagaimana dijelakan oleh Hall (1980) dan Schiller (1996). Hall menggambarkan proses ini sebagai "decoding". Proses "encoding" dalam produksi pesan adalah sebuah "proses perburuhan" (labour process) dan terdiri dari kerja interpretatif (interpretative work), aktivitas khalayak dalam mendekoding tidak dianggap sebagai kerja memproduksi makna.

Kedua, aktivitas khalayak sebagai produksi ideologi. Horkheimer dan Adorno (2002) dalam "Culture Industry" menjelaskan ekonomi politik buruh khalayak melalui keterkaitan antara budaya yang terkomodifikasi dan produksi ideologi. Industri budaya menghasilkan jenis kesamaan tertentu (Horkheimer dan Adorno, 2002: 94). Budaya diproduksi oleh industri budaya. Budaya sebagai komoditas massal adalah basis produksi penipuan massal dari ideologi. Ketiga, aktivitas khalayak sebagai buruh. Ada tiga konsep yang terkait dengan ini yaitu: buruh (labour), objek buruh (object of labour), dan insturmen buruh (instrument of labour). Proses perburuhan khalayak diabstraksikan dari bentuk spesifik ke kapitalisme. Buruh khalayak adalah orang yang memiliki aktivitas konsumsi budaya. Objek buruh khalayak adalah objek yang dipersepsi atau yang dikonsumsi oleh khalayak seperti budaya termasuk di dalamnya iklan. Instrumen buruh khalayak adalah apa yang digunakan untuk bekerja oleh buruh tadi yaitu medium komunikasi, dan semua yang terkait dengan alat komunikasi yang digunakan untuk mengonsumsi budaya.

\section{Eksploitasi Khalayak Sebagai Buruh}

Kekuatan dan kemampuan RCTI dalam menjangkau khalayak yang luas adalah modal. Jaringan ekonomi politik grup MNC dan RCTI adalah nilai tambah dalam distribusi dan terkait dengan akumulasi modal secara keseluruhan. Dengan jangkaun khalayak dan distribusi yang luas ini, RCTI menggunakan kekuasaan yang lebih ini untuk mendapatkan banyak pengiklan dan otomatis semakin kuat bentuk kontrol terhadap pekerja dan eksploitasinya terhadap khalayak sebagai 
buruh.

Symyte beranggapan bahwa khalayak merupakan komoditas, dimana pengiklan membayar saluran televisi untuk iklan yang ditayangkan. Semakin besar khalayak yang menonton, semakin banyak uang yang didapat pihak televisi (Kruger \&Johanssen, 2014: 635). Oleh karena itu, keberadaan rating sangat penting dalam industri televisi. Karena, penjualan khalayak ke pengiklan adalah bentuk komodifikasi untuk mempengaruhi keputusan para pemasang iklan dalam menempatkan iklannya dalam slot jeda iklan yang ada.

Komodifikasi terjadi ketika pengelola media memperlakukan khalayak sebagai komoditas dan sebagai buruh. Aktivitas khalayak dalam menonton adalah bentuk kegiatan produksi rating. Melalui tayangan sinetron TBNH yang bisa menyenangkan khalayak, RCTI mampu mengundang para pemasang iklan dan memperpanjang bisnis sinetron, yang ditandai dengan banyaknya jumlah episode. Kegiatan komodifikasi ini menggambarkan bahwa khalayak dieksploitasi bagi kepentingan mengakumulasi modal untuk pemilik televisi. Oleh karena itu, salah satu aspek mendasar komunikasi sebagai modal adalah dengan mengeksploitasi buruh khalayak ini untuk mensirkulasi dan mengakumulasi modal (Nixon, 2014:732).

Jadi, eksploitasi buruh khalayak sinetron ini terjadi ketika ratingnya bagus maka konflik cerita akan terus dipertahankan namun jika tidak baik maka konflik cerita akan diubah dan dicari bentuk strategi atau permasalahan yang lebih menarik lagi. Sehingga 'ketaatan' terhadap hasil rating hanya menjadikan penonton sinetron TBNH sebagai komoditas dan buruh dalam industri televisi. Rating ini terbentuk melalui proses komodifikasi yang tercipta sebagai akibat langsung dari adanya komodifikasi yang lain (Mosco, 2009:141). Komodifikasi imanen dalam bentuk rating ini merupakan permintaan penggunaan prosedur ukuran terhadap komoditas yang dihasilkan dan memonitoring teknik mengikuti standar produksi, distribusi, pertukaran dan konsumsi yang ditetapkan.

Berangkat dari rating, berbagai strategi dan modus dilakukan oleh RCTI dan Sinemart untuk mencapai tujuan yang diinginkan. Industri televisi yang selalu berpedoman pada rating ini, menganggap bahwa tingginya minat dan kesukaan khalayak untuk menonton sinetron tentu sangat menguntungkan untuk melipatgandakan modal. Tidak aneh bila
RCTI menggunakan simbol agama dalam bentuk simbol-simbol kesalehan seperti haji, masjid, pakaian muslim, jilbab, jubah atau baju koko dan sebagainya. Simbol ini menjadi kemasan produk sinetron untuk mendapatkan rating yang tinggi. Dengan demikian, produk aktivitas khalayak adalah makna, namun makna bagi pemilik modal adalah ratingnya. Jadi khalayak sebagai buruh dijadikan pekerja untuk menciptakan makna sebagai bentuk konsumsi budaya dan rating sebagai bentuk produk untuk dijual ke pengiklan.

Oleh karena itu, membahas industri televisi, tidak bisa lepas dari peran audien yang menjadi 'korban' dari eksploitasi para pemilik modal. Eksploitasi ini menimbulkan masyarakat atau khalayak yang teralienasi. Exsploitasi dan alienasi merupakah hal yang tidak bisa dipisahkan, karena keduanya saling melengkapi. Konsepsi alienasi Marx merupakan hal yang kompleks dan tumpang tindih, bersinggungan antara proses dan juga hasilnya (Fisher, 2012: 173). Oleh karena itu, antara eksploitasi dan alienasi merupakan pondasi kapitalisme-kepemilikan pribadi dan komodifikasi buruh.

Berangkat dari hal ini, masyarakat semestinya diajak dan digerakkan untuk memahami bahwa media massa sesungguhnya tidaklah netral, karena media adalah ajang kontestasi pelbagai kepentingan sosial ekonomi dan politik. Bahwa media sesungguhnya bukan sekadar alat kontrol sosial dan cermin realitas, melainkan punya peran dalam mengonstruksi realitas sosial secara subjektif (Astuti, 2004: 406). Oleh karena itu, pemodal jelas telah menjadikan khalayak sebagai komoditas dan sekaligus buruh untuk mengeruk dan mengakumulasi modal sebanyak-banyaknya. Karena semakin banyak audiens menonton, maka pengiklan semakin tertarik dan berani membayar mahal.

\section{Simpulan dan Saran}

Aktivitas konsumsi khalayak sinetron TBNH menunjukkan adanya bentuk eksploitasi terhadap khalayak oleh grup MNC untuk mengakumulasikan modal. Khalayak menjadi bagian utama yang dijadikan komoditas dan buruh dengan modus disuguhi tontonan yang isinya menyesuaikan dan mendekatkan pada konteks kehidupan beragama dan berbudaya masyarakat Islam. Aktivitas konsumsi ini merupakan bentuk memerkerjakan khalayak sebagai pekerja yang dituntut agar terus menonton untuk memproduksi rating yang tinggi, secara otomatis menghasilkan uang 
yang banyak buat pemilik media. Pekerjaan menonton terus dari episode ke episode dengan tanpa imbalan ini, adalah bentuk eksploitasi khalayak, dan di sisi lain khalayak teralienasi dari kehidupan mereka yang seharusnya.

Eksploitasi khalayak sinetron TBNH ini jelas terjadi pada umat Islam dan khususnya kaum perempuan sebagai segment dan target konsumen utama televisi ini. Dari sisi strategi pemasaran produk sinetron, strategi merebut khalayak dengan sasaran masyarakat yang mayoritas Islam adalah pasar yang sangat menjanjikan dan menggiurkan terutama bagi jenis atau genre sinetron religi. Sebagai sebuah produk industri budaya, sinetron TBNH telah menjadikan khalayak sebagai buruh yang loyal, sehingga produk sinetron ini pun terus ditayangkan.

Kajian ekonomi politik komunikasi dalam perspektif Islam atau feminis perlu dikembangkan untuk memahami dan meneliti konteks industri televisi secara lebih mendalam. Penelitian khalayak dan pekerja diharap dapat memberikan kontribusi dalam mengembangkan teori ekonomi politik komunikasi dan praktik industri manusiawi dan yang Islami. Selain itu sudah saatnya ada usaha dan gerakan yang bisa menyadarkan para pemilik media, pekerja media, khalayak dan juga pemerintah yang bisa mengubah sistem media yang otoriter dan eksploitaitif ini menjadi lebih baik.

\section{Daftar Pustaka}

Astuti, Santi Indra. (2004). "Media Literacy: Mendidik Masyarakat Cerdas di Era Informasi". Jurnal MIMBAR; Sosial dan Pembangunan. Volume XX, No. 4, 406439.

Baran, Stanly J. \& Dennis K. Davis. (2010). Teori Komunikasi Massa; Dasar, Pergolakan dan Masa Depan. Edisi 5. Terjemahan.Afrianto Daud dan Putri Iva Izzati. Jakarta: Salemba Humanika, .

Burton, Graeme. (2007). Membincangkan Televisi; Sebuah Pengantar Kepada Studi Televisi, Terjemahan Laily Rahmawati. Yogyakarta: Jalasutra.
Burton, Graeme. (2009). Media and Society: Critical Perspective. Jaipur, New Dheli: Rawat Publication.

Cetin, Kumru Berfin Emre. (2014). "The 'Politization' of Turkish Television Drama". International Journal of Communication 8 (2014).

Fisher, Eran. (2012). "How Less Alienation Creat More Explanation? Audience Labour on Social Network Sites". Triple-c: Cognition, Communication, Co-operation 10 (2). 171-183.

Kitley, Philip. (2001). Konstruksi Budaya Bangsa di Layar Kaca, Jakarta: Sembrani Aksara Nusantara.

Kruger, Steffen \& Jacob Johanssen.(2014). "Alienation and Digital Labour-A Depth-Hermeneutic Inquiry into Online Commodification and the Unconscious". Triple-c: Cognition, Communication Cooperation 12 (2).

McQuail, Denis. (2011). Teori Komunikasi Massa, Buku 1- Edisi 6. Terjemahan Putri Iva Izzati. Jakata: Salemba Humanika.

Mosco, Vincent. (2009). The Political Economy of Communication, Second Edition. New York: Sage Publication.

Nixon, Brice. (2014). "Toward a Political Economy of 'Audience Labour' in Digital Era". Triple-C: Journal for Global Sustainable Information Society: 12 (2).

Ritzer, Geroge.(2012). Teori Sosiologi: Dari Sosiologi Klasik Sampai Perkembangan Terakhir Postmodern. Penerjemah Saut Pasaribuh, Rh. Widada, Eka Adi Nugraha. Yogyakarta: Pustaka Pelajar.

Sulaiman, Adhi Iman. (2010). "Dilema Elit Politik dan Kekuatan Media Massa". Jurnal MIMBAR; Sosial dan Pembangunan. Volume XXVI, No. 2, 115-121.

Suseno, Franz Magnis. (2000). Pemikiran Karl Marx: dari Sosialisme Utopis Ke Perselisihan Revisionisme. Jakarta: Gramedia.

Syahputra, Iswandi. (2011). Rahasia Simulasi Mistik Televisi. Yogyakarta: Pustaka Pelajar.

Syahputra, Iswandi (2013). Rezim Media; Pergulatan Demokrasi, Jurnalisme dan Infotainment dalam Industri Televisi. Jakarta: Gramedia Pustaka Utama. 